\title{
Analysis of Arg-Gly-Asp mimetics and soluble receptor of tumour necrosis factor as therapeutic modalities for concanavalin $\mathrm{A}$ induced hepatitis in
} mice

\author{
R Bruck, H Shirin, R Hershkoviz, O Lider, G Kenet, H Aeed, Z Matas, L Zaidel, \\ Z Halpern
}

\begin{abstract}
Background/Aims-It has been shown that synthetic non-peptidic analogues of Arg-Gly-Asp, a major cell adhesive ligand of extracellular matrix, prevented an increase in serum aminotransferase activity, as a manifestation of concanavalin $A$ induced liver damage in mice. This study examined the effects of an ArgGly-Asp mimetic on liver histology and cytokine release in response to concanavalin $A$ administration, and the efficacy of soluble receptor of tumour necrosis factor (TNF) $\alpha$ in preventing hepatitis in this model of liver injury.
\end{abstract}

Methods-Mice were pretreated with either the Arg-Gly-Asp mimetic SF-6,5 or recombinant soluble receptor of $\mathrm{TNF} \alpha$ before their inoculation with $10 \mathrm{mg} / \mathrm{kg}$ concanavalin A. Liver enzymes, histology, and the serum values of TNF $\alpha$ and interleukin (IL)6 were examined.

Results-The histopathological damage in the liver, and the concanavalin $A$ induced release of TNF $\alpha$ and IL6 were significantly inhibited by the synthetic Arg-Gly-Asp mimetic $(p<0 \cdot 001)$. Liver injury, manifested by the increase in serum aminotransferase and cytokines, as well as by histological manifestations of hepatic damage, was effectively prevented by pretreatment of the mice with the soluble TNF receptor $(p<0 \cdot 001)$.

Conclusions-This study confirms the efficacy of a synthetic Arg-Gly-Asp mimetic and soluble TNF receptor in the prevention of immune mediated liver damage in mice.

(Gut 1997; 40: 133-138)

Keywords: cytokines, hepatitis, RGD mimetics, T lymphocytes, Arg-Gly-Asp acid, concanavalin A.

The E Wolfson Medical Centre Holon, Israel

Department of Cell Biology, The

Weizmann Institute of Science, Rehouot, Israel

R Hershkoviz

O Lider

Correspondence to:

Dr R Bruck,

Department of

Gastroenterology, The E

Wolfson Medical Centre Holon 58100, Israel.

Accepted for publication 29 July 1996 nisable by a significant increase in serum aminotransferases six to eight hours after the intravenous administration of Con A. ${ }^{1}$ It has been suggested that CD4 bearing helper $T$ lymphocytes are involved as effector cells of Con $\mathrm{A}$ induced damage. ${ }^{1}$ The induction of
Con A hepatitis depends on the interaction between $\mathrm{CD}^{+} \mathrm{T}$ helper cells and macrophages, ${ }^{1}$ and as recently reported, on the production of cytokines, notably tumour necrosis factor (TNF) $\alpha$ and interleukin (IL) $2 .^{2}{ }^{3}$ When examined six to eight hours after inoculation of the lectin, Con A treated mice demonstrated significant discrepancy between the massive aminotransferase release, compared with the minimal histopathological changes seen by light microscopy, although electron microscopic examination showed severe changes as early as four to six hours after Con A administration. ${ }^{1}$ In later studies, however, severe histopathological changes could be demonstrated by light microscopy in Con A treated mice, when livers were fixed 24-72 hours after the inoculation of Con A. ${ }^{3}$

Recently, we have shown that administration of synthetic, non-peptidic analogues of the cell adhesion motif Arg-Gly-Asp (RGD), which mediates binding of certain $\beta_{1}$ integrins to several extracellular matrix (ECM) glycoproteins, inhibited a Con $\mathrm{A}$ induced increase in serum aminotransferase activity in mice, when given before inoculation with the lectin. ${ }^{4}$ However, in this study, mice were killed and their livers examined six hours after Con A administration. Therefore, we were unable to demonstrate the histological damage induced by Con $A$ or its prevention by the RGD analogues. Furthermore, the effect of these compounds on the production of cytokines, such as $\mathrm{TNF} \alpha$ in response to Con A was not examined.

Hepatic injury in Con A induced hepatitis is mediated primarily by $\mathrm{TNF} \alpha$, and this damage could be prevented by the use of polyclonal TNF $\alpha$ antiserum. ${ }^{3}$ Recombinant soluble TNF receptors (sTNF-R) have been developed and can be used to neutralise TNF $\alpha$ in vivo. ${ }^{5}$ Therefore, in this study, sTNF-R was used to prevent Con $\mathrm{A}$ induced liver damage and to confirm the main role of $T N F \alpha$ in Con A induced hepatitis.

We have demonstrated that liver inflammation in Con A treated mice, characterised by areas of necrosis and infiltration of liver tissue by mononuclear cells, predominantly $\mathrm{CD}^{+} \mathrm{T}$ lymphocytes, could be prevented by a synthetic analogue of the RGD sequence and by sTNF-R. Moreover, the Con A induced increases in serum TNF $\alpha$ and IL6, were also abolished by pre-treatment of mice with either 
the RGD mimetic or sTNF-R. These results show, that inhibition of a Con $A$ induced increase in TNF $\alpha$ by the synthetic RGD mimetic or by soluble TNF receptor, effectively prevents immune mediated Con A induced liver damage in mice.

\section{Methods \\ Induction and evaluation of liver injury}

$\mathrm{BALB} / \mathrm{c}$ mice were maintained at the Animal Breeding Centre of the $\mathrm{E}$ Wolfson Hospital. To induce acute liver injury, six to eight week old male mice were injected with $10 \mathrm{mg} / \mathrm{kg}$ Con A (Sigma, St Louis, MO) in $250 \mu l$ phosphate buffered saline (PBS) administered via the tail vein. ${ }^{1}$ Twenty four hours after the administration of Con A, mice were bled and then under chloral hydrate anaesthesia their abdomen was opened by a midline incision and sections from left liver lobe were excised for histopathological examination. Liver sections were fixed in a $5 \%$ neutral formol solution and stained with haematoxylin and eosin. Immunohistochemistry was performed by the immunoperoxidase technique to stain CD4 positive $T$ lymphocytes in liver tissue.

Treatment of animals was in accordance with guidelines of The Weizmann Institute of Science and Tel-Aviv University.

\section{Staining for $C D 4^{+} T$ lymphocytes}

Paraffin wax sections were cut at $3 \mu \mathrm{m}$ and stained by using the labelled-(strep) avidinBiotin (LAB-SA) method, also known as streptavidin-biotin amplification (HistostainSP (peroxidase) Bulk Kit Zymed Laboratories). Sections were deparaffinised and hydrated. Endogenous peroxidase was blocked with $3 \%$ hydrogen peroxide for five minutes. Sections were washed in running tap water and placed in TRIS buffered saline (TBS) at $\mathrm{pH}$ 7.6. Primary antibody, monoclonal mouse antihuman $\mathrm{T}$ cell, Helper (Zymed Laboratories, San Francisco) at optimal dilution, was then applied for 60 minutes at room temperature. Sections were rewashed in TBS and the bridge antibody, a biotinylated secondary antibody, was then applied for 10 minutes at room temperature. Sections were rewashed again in TBS and streptavidin peroxidase conjugated was applied for 10 minutes at room temperature. A further wash in TBS was followed by staining with 3-amino-9-ethylcarbazole (AEC (red) Substrate kit, Zymed Laboratories) for five minutes to develop the colour, counterstaining with Mayer's haematoxylin and mounting solution.

\section{Biochemical assessment of liver injury}

The extent of liver injury was estimated, in addition to histopathological examination, by determining the serum values of alanine aminotransferase (ALT), and aspartate aminotransferase (AST), using an automated Monarch monoanalyser.
Determination of serum $T N F \alpha$ and IL6 in Con A treated mice

Mice sera were drawn two, six, 24, 72, and 96 hours after Con A administration for the measurement of TNF $\alpha$ and IL6 levels, in control mice (pretreated with $\mathrm{NACl} 0.9 \%$ or the RGE mimetic SF-6,6) and in those pretreated with the RGD analogue SF-6,5 and soluble TNF receptor.

MaxiSorp F96 microtitre plastic plates (Nunc Inter Med) were coated with $2 \mu \mathrm{g} / \mathrm{ml}$ IL6 and IL10 $\mathrm{mAB}$ in $0 \cdot 1 \mathrm{NaCO} 3$ at $\mathrm{pH} 8 \cdot 2$ (overnight at $48^{\circ} \mathrm{C}$ ). Plates were washed (two cycles) with PBS-0.05\% TWEEN 20 (v/v) (Bio-Rad Laboratories). Then, the coated plates were blocked with PBS-10\% FCS (Biolab) for one hour at room temperature. One hundred $\mu \mathrm{l}$ of diluted 1:4 mice serum derived from the various treatment groups were incubated overnight at $4^{\circ} \mathrm{C}$, followed by four cycles of washing. Biotinylated anticytokine detecting antibody $(2 \mu \mathrm{g} / \mathrm{ml}$ diluted in PBS-10\% fetal calf serum) was incubated in all wells for two hours at room temperature and washed for six cycles. Alkaline phosphatase conjugated streptavidin (Jackson ImmunoResearch Laboratories) was used to detect the bound biotinylated anticytokine antibody by incubating $1.5 \mu \mathrm{g} / \mathrm{ml}$ in PBS-10\% fetal calf serum for 30 minutes at room temperature. p-Nitrophenyl phosphate (Sigma) $0.5 \mathrm{mg} / \mathrm{ml}$ together with $9.7 \%$ DietanolAmine 9 in water) pH 9.8 were used as chromagen. Wells were read at a single $405 \mathrm{~nm}$ wavelength.

\section{Recombinant soluble TNF receptor}

Recombinant human soluble TNF receptor (sTNF-R, Interpham, Israel), was produced in CHO (chinese hamster ovaries) cells and purified by immunoaffinity column, using mABs to the sTNF-R1. Purity $>95 \%$ was verified by SDS PAGE and size exclusion HPLC. sTNF-R at TNF:sTNF-R molar ratio of $1: 10^{2}, 1: 10^{3}$, and $1: 10^{4}(1,10$ and 100 $\mu \mathrm{g} / \mathrm{mouse}$ ), was administered intraperitoneally, one hour before Con A injection.

\section{Non-peptidic mimetics of RGD}

Compounds SF-6,5 and SF-6,6 (the synthetic analogues of RGD and RGE, respectively) were prepared as previously described. ${ }^{6}{ }^{7}$ Briefly, SF6,5 was prepared by coupling methyl-5-aminovaleric acid with $N$-butyloxycarbonyl-6-aminohexanoic acid by 1,3-dicyclohexyl-carbodiimide and 1-hydroxybenzotriazole in tetrahydrofuran. Next, the butyloxycarbonyl protecting group was removed, and the amine was converted into guanidinium using 3,5-dimethylpyrazole1-carboxamidine nitrate. Compound SF-6,6 was prepared from methyl-6-aminohexanoic acid and $N$-butyloxycarbonyl-6-aminohexanoic acid using the same procedure. SF- 6,5 and SF6,6 were characterised and their purity (over $97 \%$ ) was determined by high performance liquid chromatography. Compound SF-6,5, a non-peptidic mimetic of RGD, which has a 11-carbon atom spacer between the guanidinium and carboxyllic groups that mimics the 
atomic spacing between the two functional groups in the RGD peptide, was synthesised. The RGE (Arg-Gly-Glu acid) mimetic, SF-6,6, was synthesised to be used as control. ${ }^{8}$

The RGD mimetics were dissolved in PBS and administered intraperitoneally before the induction of liver injury by Con A, and daily for five days before administration of Con $\mathrm{A}$.

\section{Statistical analysis}

The data are presented as the means (SD). The significance of differences between different groups was determined by unpaired $t$ test.

\section{Results}

Inhibition of Con $A$ induced enzymes release by $S F-6,5$

$\mathrm{BALB} / \mathrm{c}$ mice were injected intravenously with $10 \mathrm{mg} / \mathrm{kg}$ Con $\mathrm{A}$, and treated with $500 \mathrm{mg} /$ mouse of the RGD analogue SF- 6,5 or the RGE analogue SF-6,6 (as a control group). It has been shown recently that (a) the RGD analogue had a maximal effect in preventing Con A induced liver damage at a dose of 500 $\mu \mathrm{g} /$ mouse, and (b) the native RGD peptide (GRGDSP) was comparatively ineffective probably because of its in vivo sensitivity to proteolytic degradation. ${ }^{4}$ In this study, mice were killed 24 hours after Con A injection to enable the development of a demonstrable histological damage (Table I). In previous studies, only mild inflammation could be shown by light microscopy when livers were examined six to eight hours after Con A injection. ${ }^{1}$

As expected, the control RGE mimetic, SF6,6 , which has a 12-atom spacing chain between the two ionic functional groups, and therefore lacks integren specificity, did not prevent liver damage and had no effect on the release of liver enzymes or on microscopic liver damage induced by Con A inoculation (data not shown). In contrast, the RGD mimetic SF6,5 at a dose of $500 \mu \mathrm{g} / \mathrm{mouse}$ (given for five days before Con A administration) effectively

TABLE I Effect of Con $A$ on liver enzyme and cytokine release

\begin{tabular}{llcll}
\hline $\begin{array}{l}\text { Hours afterCon } A^{\star} \\
\text { administration }\end{array}$ & $\begin{array}{l}\text { AST } \\
(I U /)\end{array}$ & $\begin{array}{l}A L T \\
(I U /)\end{array}$ & $\begin{array}{l}\text { TNF } \\
(\mathrm{pg} / \mathrm{ml})\end{array}$ & $\begin{array}{l}\text { IL6 } \\
(\mathrm{pg} / \mathrm{ml})\end{array}$ \\
\hline 2 & $320(47)$ & $560(92)$ & $600(95)$ & $13000(2100)$ \\
6 & $3500(630)$ & $4420(650)$ & $180(25)$ & $1700(250)$ \\
24 & $2422(311)$ & $4105(473)$ & $50(10)$ & $160(38)$ \\
48 & $450(76)$ & $700(58)$ & $30(5)$ & $40(12)$ \\
96 & $45(18)$ & $48(9)$ & $12(3)$ & $40(10)$ \\
\hline
\end{tabular}

Mean (SD), $\mathrm{n}=5$; ${ }^{\star}$ Con A, $10 \mathrm{mg} / \mathrm{kg}$. The RGE mimetic SF-6,6 that served as control, had no effect on the liver injury induced by Con $A$, and the levels of hepatic enzymes and cytokines were similar to the group that received Con A alone (data not shown).

TABLE II Effect of the RGD mimetic SF-6,5† on levels of liver enzymes and cytokine release in Con $A$ treated mice

\begin{tabular}{lllll}
\hline $\begin{array}{l}\text { Hours after Con } A^{\star} \\
\text { administration }\end{array}$ & $\begin{array}{l}A S T \\
(I U /)\end{array}$ & $\begin{array}{l}A L T \\
(I U /)\end{array}$ & $\begin{array}{l}\text { TNF }) \\
(\mathrm{pg} / \mathrm{ml})\end{array}$ & $\begin{array}{l}\text { IL6 } \\
(\mathrm{pg} / \mathrm{ml})\end{array}$ \\
\hline 2 & $110(18)^{\star}$ & $118(33)^{\star}$ & $188(21)^{\star}$ & $2500(350)^{\star}$ \\
6 & $152(38)^{\star}$ & $158(32)^{\star}$ & $52(8)^{\star}$ & $950(112)^{\star}$ \\
24 & $147(23)^{\star}$ & $167(30)^{\star}$ & $30(7)$ & $94(16)$ \\
48 & $68(16)^{\star}$ & $104(19)^{\star}$ & $21(5)$ & $30(8)$ \\
96 & $51(12)^{*}$ & $55(12)$ & $15(4)$ & $28(5)$ \\
\hline
\end{tabular}

Mean (SD); n=5; Con A, $10 \mathrm{mg} / \mathrm{kg}$; ${ }^{\star} \mathrm{p}<0.001$ compared with Con A alone; $\uparrow 500 \mu \mathrm{g} / \mathrm{mouse}$. decreased the high serum values in both liver enzymes tested $(p<0.001)$; Table II). When SF-6,5 was administered at a single dose of 500 $\mu \mathrm{g} /$ mice one hour before Con A injection, the increase in serum levels of liver enzymes was inhibited by only $50 \%$ (data not shown). We concluded from our present and previous studies that pre-treatment of the animals with the RGD mimetic for five days was optimal to prevent $T$ cell dependent immune mediated events in mice, such as Con A hepatitis ${ }^{4}$ or delayed type hypersensitivity reaction. ${ }^{9}$

Inhibition of $T N F \alpha$ and IL6 release by $S F-6,5$ As reported recently, Con A induced hepatic injury is mediated by cytokines such as TNF $\alpha$, IL $2^{1-3}$ and IL-6. ${ }^{3}$ Therefore, we performed serial measurements of serum values of $\mathrm{TNF} \alpha$ and IL6, two, six, 24, 72, and 96 hours after Con A administration in a control group (treated with Con A only) and in a group of mice that were pretreated with the RGD mimetic SF-6,5 before Con A administration. As shown in Table II, the increase in serum values of both cytokines - that is, TNF $\alpha$ and IL6 in response to Con A, was prevented by pretreatment with the RGD mimetic SF-6,5. Serum values of $T N F \alpha$ in the Con A treated mice increased after two hours to $600(95) \mathrm{pg} /$ $\mathrm{ml}$ compared with $188(21) \mathrm{pg} / \mathrm{ml}$ in the SF6,5 treated mice. Serum TNF values in the SF6,5-treated group were significantly lower also when determined after six and 24 hours from Con A administration $(p<0.001$, Table II). The increase in serum values of IL6 two hours after Con A injection, was inhibited in the SF6,5 treated mice from $13000(2100) \mathrm{pg} / \mathrm{ml}$ in the control mice (treated only with Con A), to $2500(350) \mathrm{ng} / \mathrm{ml}$ in animals treated with Con $A$ and the RGD analogue ( $p<0 \cdot 001$, Table II). Mice treated with Con A only had aminotransferase values similar to those pretreated with the RGE mimetic SF-6,6. These results show that the prevention of Con $A$ induced liver injury by the RGD mimetic, which is associated with a decrease in cell migration through ECM barriers to inflammatory loci, ${ }^{6}$ is also associated with inhibition of cytokine release, for example, TNF $\alpha$ and IL6.

\section{Effects of the RGD mimetic SF-6,5 on liver histology}

To determine the extent of liver damage, and the efficacy of the treatment described, mouse liver sections fixed 24 hours after Con A administration were examined microscopically. Livers of control rats, treated with Con A only or with the inactive RGE analogue SF-6,6, showed widespread areas of necrosis and inflammation within the liver lobules and around the central veins and the portal tracts (Figure (A)). Inflammatory infiltrates consisted mainly of mononuclear cells, many of which were positively stained by anti-CD4 by immunohistochemistry (Figure (B)). Compatible with previous studies, these results further establish the important role of the $\mathrm{CD}^{+} \mathrm{T}$ cell subpopulation in the aetiology 

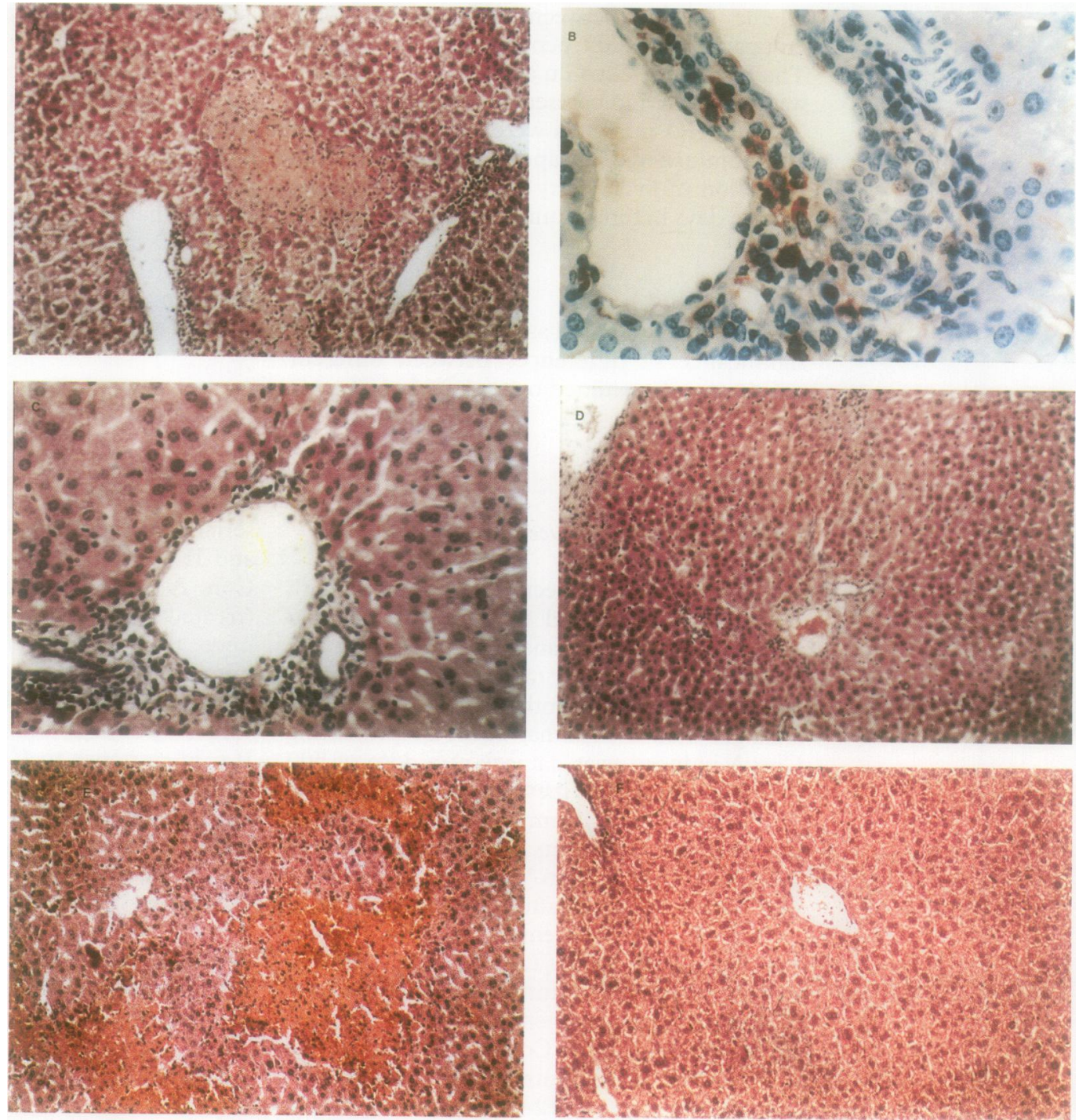

(A): A section of mouse liver from a control group 24 hours after treatment with $10 \mathrm{mg} / \mathrm{kg}$ Con $A$, shows widespread areas of necrosis and inflammation within the liver lobules and around central veins and the portal tracts. Haematoxylin and eosin, original magnification $\times 80$. (B): Inflammatory infiltrates in the livers of Con A treated mice consisted predominantly of mononuclear cells, many of which stained positive for $C D 4$ by immunoperoxidase technique. Original magnification $\times 240$. $(C)$ : The non-active $R G E$ mimetic $S F-6,6$, which does not bind integrin receptors and was used as control, did not prevent liver inflammation induced by the administration of $10 \mathrm{mg} / \mathrm{kg}$ Con A. Haematoxylin and eosin, original magnification $\times 160$. (D): A section of a mouse liver treated with $10 \mathrm{mg} / \mathrm{kg}$ Con $A$ and the RGD mimetic SF-6,5. In this group, liver damage was minimal: no areas of intralobular necrosis or significant inflammatory infiltration could be demonstrated. Haematoxylin and eosin, original magnification $\times 80$. (E): A section of mouse liver from a control group 24 hours after treatment with $10 \mathrm{mg} / \mathrm{kg}$ Con $A$, shows necrosis and inflammation within the liver lobules and around central veins and the portal tracts. Haematoxylin and eosin, original magnification $\times 80 .(F):$ A mouse liver, pretreated with $s T N F R, 24$ hours after Con A administration. Note that liver damage was prevented and liver histology shows no necrosis or inflammation. In sections of sTNF-R treated mice, taken two and six hours after Con A injection, apoptosis of liver cells could not be seen and liver histology was almost normal. Haematoxylin and eosin, original magnification $\times 80$.

and pathogenesis of Con $\mathrm{A}$ induced hepatitis. ${ }^{3}$ As expected, the control RGE mimetic SF-6,6 that does not bind integrins did not prevent the apparent liver inflammation (Figure (C)). In contrast, in mice treated by the RGD analogue SF-6,5 liver damage was minimal: no areas of intralobular necrosis or significant inflammatory infiltration could be shown by light microscopy (Figure (D)). These results provide histopathological evidence to the reported inhibition of the liver enzymes ${ }^{4}$ and cytokine release, by the RGD mimetics.

Inhibition of liver damage by soluble TNF receptor

The in vivo protective effects of recombinant preparations of the p55 TNF receptor
(sTNF-R) were assessed in mice by monitoring the serum values of hepatic enzymes in response to Con A administration. sTNF-R, at a molar ratio of $1: 10^{2}$ or $1: 10^{3}$ to $T N F \alpha$ ( 1 or $10 \mu \mathrm{g} /$ mouse respectively, based on $\mathrm{TNF} \alpha$ serum value measured two hours after Con $A$ inoculation), had no effect on the release of aminotransferase (not shown). However, sTNF-R, at a molar ratio of $1: 10^{4}$ to TNF $\alpha$ (100 $\mu \mathrm{g} / \mathrm{mouse}$ ), effectively inhibited the Con $A$ induced increase of serum values of hepatic enzymes and of the cytokines TNF $\alpha$ and IL6 $(p<0.001$; Table III). Thus, in vivo administration of sTNF-R, which inhibits the increase of serum TNF values in response to Con A, seems to decrease the biochemical manifestations of experimentally induced liver damage. 
TABLE III Effect of sTNF-R $\left(1: 10^{4}\right) \dagger$ on Con $A$ induced liver injury in mice

\begin{tabular}{lllll}
\hline $\begin{array}{l}\text { Hours after Con } A^{\star} \\
\text { administration }\end{array}$ & $\begin{array}{l}\text { AST } \\
(I U /)\end{array}$ & $\begin{array}{l}A L T \\
(I U /)\end{array}$ & $\begin{array}{l}\text { TNFa } \\
(p g / m l)\end{array}$ & $\begin{array}{l}\text { IL6 } \\
(p g / m l)\end{array}$ \\
\hline 2 & $141(21)^{\star}$ & $64(11)^{\star}$ & $130(17)^{\star}$ & $2200(310)^{\star}$ \\
6 & $111(21)^{\star}$ & $56(8)^{\star}$ & $60\left(10^{\star}\right.$ & $650(104)^{\star}$ \\
24 & $118(27)^{\star}$ & $22(5)^{\star}$ & $30(5)^{\star}$ & $60(18)^{\star}$ \\
48 & $56(15)^{\star}$ & $20(4)^{\star}$ & $20(4)$ & $38(7)$ \\
96 & $37(14)^{*}$ & $18(4)$ & $12(3)$ & $34(8)$ \\
\hline
\end{tabular}

Mean (SD); ${ }^{\star} \mathrm{p}<0.001$ compared with Con A alone; $\mathrm{n}=5$; Con A, $10 \mathrm{mg} / \mathrm{kg}$; †molar ratio TNF:sTNF-R.

\section{Effect of STNF-R on liver histology in Con A treated mice}

Livers of control rats, treated with Con A only, showed widespread areas of necrosis and inflammation within the liver lobules and around the central veins and the portal tracts (Figure (E)). As shown in Figure $(F)$, liver damage was almost entirely prevented by the administration of the STNFR at a molar ratio of $1: 10^{4}$ to TNF $\alpha$.

It has been reported that apoptosis of liver cells is an early event in Con A induced hepatitis, which could be shown histopathologically as early as three hours after the inoculation of Con A. ${ }^{2}$ In this study, apoptosis of liver cells could not be detected two and six hours after the injection of Con $A$, in liver sections taken from rats treated with sTNF-R, suggesting that sTNF-R prevents TNF induced apoptosis of liver cells and it may explain the protective effect of sTNF-R from Con $\mathrm{A}$ induced liver injury.

\section{Discussion}

In most liver diseases, inflammatory infiltrate can be shown histologically. The inflammatory cell infiltrate is thought to contribute to liver injury either as a primary event, as in autoimmune hepatitis, or as a secondary response to another process such as chronic viral infection. Each cellular component of the immune system has a specific mechanism by which it may damage liver cells. This specificity provides a rationale and an opportunity for directed intervention to prevent liver injury during inflammation. In several liver diseases, such as chronic viral hepatitis, primary biliary cirrhosis, autoimmune chronic active hepatitis, and primary sclerosing cholangitis, $\mathrm{T}$ lymphocytes serve as effector cells of the immunostimulatory processes. In response to liver injury, $T$ cell activation results in production of cytokines such as TNF $\alpha$ and IL2, which maintain and augment the level of the inflammatory process and may induce acute toxicity. ${ }^{9}$ Recently, an animal model of immune mediated liver damage was introduced in mice. In this experimental model, the disease develops after a single injection of the lectin Con A. ${ }^{1}$ This mouse model of acute liver damage, might be useful for the investigation of the pathogenesis and the efficacy of experimental treatment modalities in chronic hepatic inflammation as well, as similar processes take place during an immune response to chronic liver insult.

The migration of immune cells from the blood vessels and their accumulation at sites of tissue injury depends on their penetration through the subendothelial basement membrane, interstitial stroma, and extracellular matrix (ECM). ${ }^{10}{ }^{11}$ Cellular interactions with ECM components are regulated primarily via the $\beta_{1}$ subfamily of integrin receptors. ${ }^{10} 1213$ The target epitope of several such integrin receptors is the RGD sequence, a cell adhesion motif shared by several matrix associated adhesive glycoproteins, such as fibronectin, vitronectin, fibrinogen, thrombospondin, and von Willebrand factor. ${ }^{1415}$ The use of RGD containing peptides to prevent $\mathrm{T}$ cell mediated inflammatory reactions in vivo is not practical because these peptides are highly susceptible to proteolysis, and thus high concentration of the RGD peptides are needed for such treatments. $^{16}$

Recently we have described the design and synthesis of non-peptidic mimetics of the RGD sequence. These novel RGD mimetics contain guanidinium and carboxylic groups separated by an 11-carbon atom spacer, thus mimicking the functional groups of RGD. ${ }^{8}$ These compounds specifically inhibited (a) RGD dependent platelet aggregation, and (b) binding of $T$ lymphocytes and tumour cells to immobilised fibronectin and vitronectin. ${ }^{6}$ In addition, RGD mimetics inhibit delayed type hypersensitivity reactions and tumour cell colonisation in mice, ${ }^{6-8}$ suggesting the involvement of RGD recognition in the regulation of immune cell migration and subsequent pathological processes. In a previous study, we have shown that two synthetic analogues of RGD (SF-6,5 and NS-11) effectively prevented the elucidation of a Con $\mathrm{A}$ induced increase in liver enzymes in mice, as the manifestation of $\mathrm{T}$ cell mediated liver damage. ${ }^{4}$ In this study, we examined whether the RGD analogue SF- 6,5 also prevents histological damage and cytokine release in response to Con A administration. Liver sections, taken 24 hours after Con A administration, showed that this compound inhibited the recruitment and accumulation of mononuclear inflammatory cells, predominantly CD4+ $\mathrm{T}$ lymphocytes, in liver tissue. These histological findings provide direct evidence to the capability of the synthetic RGD mimetic to prevent Con A induced, immune mediated liver damage, and further support our previous results, showing the suppression of aminotransferase release in this model. ${ }^{4}$ In this study the RGD mimetic also decreased the production of TNF $\alpha$ and IL6 induced by Con A (Table II), suggesting that inhibition of the interaction between $T$ lymphocytes and the ECM effectively prevents the elucidation of cytokine response, and might explain the protective effect of these compounds against Con A hepatitis.

In this study, we also examined whether the use of sTNF-R prevents the biochemical and histopathological manifestations of Con A induced liver damage because the hepatic injury in this model is mediated primarily by TNF $\alpha$, and could be prevented by the use of polyclonal TNF $\alpha$ antiserum ${ }^{2}$ or anti-TNF monoclonal antibodies. ${ }^{3}$ Our results suggest that sTNF-R inhibited the rise of hepatic 
enzymes and cytokine release, and prevented the necroinflammatory changes in liver tissue, in response to Con A administration (Table III and Figure $(F)$ ). sTNF-R also prevented Con $A$ induced liver cell apoptosis as shown in liver sections taken two and six hours after Con A injection. These data are consistent with previous studies that suggested a pivotal role for $\mathrm{TNF} \alpha$ in the induction of Con A induced liver injury in mice, ${ }^{1-3}$ and confirm for the first time that neutralisation of endogenous $\mathrm{TNF} \alpha$ by sTNF-R, can prevent liver injury in this model. In a recent study, the use of STNF-R prevented acute toxic liver injury induced by $\mathrm{CCl}_{4}$, indicating a major role for $\mathrm{TNF} \alpha$ as a mediator of $\mathrm{CCl}_{4}$ toxicity. ${ }^{5}$ We also confirm in this study, that non-peptidic analogues of the cell adhesion motif RGD, can prevent the localisation of immune cells to liver tissue in certain pathological disorders, characterised by injury to hepatocytes by activated $\mathrm{CD}^{+} \mathrm{T}$ lymphocytes and macrophages. These novel compounds may be considered therapeutically to inhibit immune mediated pathological conditions in the liver.

This work was supported by a grant from the chief scientist, Ministry of Health, Israel.

1 Tiegs G, Hentchel J, Wendel A. A T cell-dependent experimental liver injury in mice inducible by Concanavalin $A$. f Clin Invest 1992; 90: 196-203.

2 Gantner F, Leist M, Lohse AW, Germann PG, Tiegs G. Concanavalin A-induced T-cell-mediated hepatic injury in mice: the role of tumor necrosis factor. Hepatology 1995; 21 : $190-8$.
3 Mizuhara H, O'Neill E, Seki N, Ogawa T, Kusunoki C, Otsuka $\mathrm{K}$, et al. $\mathrm{T}$ cell activation-associated hepatic injury: mediation by tumor necrosis factors and protection by interleukin 6. F Exp Med 1994; 179: 1529-37.

4 Hershkoviz R, Lider O, Bruck R, Aeed H, Greenspoon N, Halpern $Z$. Treatment of immune cell-mediated liver damage by nonpeptidic mimetics of the extracellular matrix-associated Arg-Gly-Asp epitope. $\mathcal{F}$ Hepatol 1995; 22: 158-64.

5 Czaja MJ, Xu J, Alt E. Prevention of carbon tetrachlorideinduced rat liver injury by soluble tumor necrosis factor receptor. Gastroenterology 1995; 108: 1849-54.

6 Hershkoviz R, Greenspoon N, Mekori YA, Hadari R, Alon R, Lider O. Inhibition of CD4+ T lymphocyte binding to fibronectin and immune-cell accumulation in inflammatory sites by novel peptidic mimetics of the Arg-GlyAsp cell adhesion motif. Clin Exp Immunol 1994; 95: $270-6$.

7 Hardan I, Hershkoviz R, Greenspoon N, Weiss l, Alon R Cahalon $\mathrm{L}$, et al. Inhibition of metastatic cell colonization in murine lungs and tumor-induced morbidity by nonpeptidic mimetics of the Arg-Gly-Asp motif. Int 7 Cancer 1993; 55: 1-6.

8 Greenspoon $\mathrm{N}$, Hershkoviz $\mathrm{R}$, Alon $\mathrm{R}$, Varon $\mathrm{D}$, Shemkman B, Marx G, et al. Selective inhibition of integrin-mediated platelet and $T$ cell function by novel integrin-mediated platelet and T cell function by nove organic surrogates of the Arg-Gly-A
motif. Biochemistry 1993; 32: 1001-8.

9 Miethke T, Wahl C, Heeg K, Echtenacher B, Krammer PH, Wagner $\mathrm{H}$. T cell-mediated lethal shock triggered in mice by the superantigen Staphylococal enterotoxin B: critica role of tumor necrosis factor. $F$ Exp Med 1992; 175 91-8.

10 Springer TA. Adhesion receptors of the immune system Nature 1990; 346: 425-34

11 Hynes RO. Integrins: versatility, modulation, and signaling in cell adhesion. Cell 1992; 69: 11-25.

12 Ruoslahti E. Integrins. F Clin Invest 1991; 87: 1-5.

13 Ruoslahti E. Fibronectin and its receptors. Annu Rev Biochem 1988; 57: 375-93.

14 D'Souza SE, Ginsberg MH, Plow EF. Arginyl-GlycilAspartic acid (RGD): a cell adhesion motif. TIBS 1991, 16: $246-50$.

15 Shimuzu Y, van Seventer GA, Horgan KJ, Shaw S. Regulated expression and binding of three VLA ( $\beta 1)$ integrin receptors on T cells. Nature 1990; 345: 250-3.

16 Ferguson TA, Mizutani H, Kupper TS. Two integrinbinding peptides abrogate $\mathrm{T}$ cell-mediated immune responses in vivo. Proc Natl Acad Sci USA 1991; 88 8072-6. 